\title{
PERSEPSI GURU TERHADAP SUPERVISI OLEH KEPALA SEKOLAH DAN KETERKAITANNYA DENGAN KINERJA GURU SMPN 99 JAKARTA
}

\author{
Irmawati $^{*}$
}

\begin{abstract}
The objective of this study is to find out the relationship between teacher perception to supervision by headmaster and performance of the teachers in SMP 99 Jakarta. This research is done at SMPN 99 Jakarta for three months since June until August 2009. Method of the research are quantitative method. Target population are 57 and samples are 30 respondents by using simple random sampling. Questionnaire is used to collecting data. This research bring into the conclusion that are relationship between teacher perception to supervision by headmaster and performance of the teachers, in other words the performance of those teachers might be influenced by their supervision.
\end{abstract}

Keywords: Perception, supervision, and performance.

\section{PENDAHULUAN}

Guru sebagai pendidik dan pengajar merupakan salah satu faktor yang sangat menentukan keberhasilan suatu usaha pendidikan. Guru merupakan ujung tombak pendidikan, yaitu merupakan tokoh yang sangat berpengaruh terhadap mutu pendidikan dalam melahirkan sumber daya manusia yang berkualitas. Guru merupakan sumberdaya manusia yang harus dikembangkan, sehingga perlu diberikan pembinaan secara terus menerus untuk mengembangkan profesionalismenya sesuai dengan kemajuan pengetahuan dan teknologi yang sesuai dengan tuntutan zaman.

Supervisi merupakan sarana untuk mengembangkan profesionalisme guru dalam usaha peningkatan kinerja guru. Supervisi bukanlah suatu kegiatan untuk mengawasi pelaksanaan tugas guru tetapi kegiatan yang bertujuan membantu guru dalam melaksanakan tugasnya. Dalam supervisi terdapat tiga aspek pokok yang memiliki peran penting dalam usaha peningkatan kinerja guru. Tiga aspek tersebut adalah pembinaan, motivasi dan pelatihan. Supervisi dalam hal ini bukan berarti mengawasi pelaksanaan tugas guru melainkan untuk dapat memberikan pembinaan yang tepat kepada guru. Sedangkan pembinaan bertujuan untuk membantu kegiatan sekolah. Namun sangat disayangkan yang terjadi di lapangan adalah supervisi jarang sekali dilakukan dan belum dilaksanakan secara optimal. Supervisi yang hanya menekankan pada aspek teknis administrasi persiapan mengajar saja seperti pembuatan silabus dan rancangan pembelajaran dengan mengabaikan aspek profesionalisme tidak akan membawa supervisi pada proses bimbingan dan pembinaan terhadap guru melainkan hanya sebagai proses pengawasan terhadap pelaksanaan tugas guru. Selain itu hingga saat ini supervisi yang terjadi menggunakan jalur searah dari atas ke bawah. Supervisi selalu datang atas inisiatif kepala sekolah dan bukan datang dari guru sebagai orang yang merasa perlu dibina. Hal ini disebabkan karena guru sudah merasa berpengalaman sehingga tidak merasa perlu belajar lagi. Selain itu hubungan profesional yang kaku antara kepala sekolah (supervisor) dengan guru yang menjadi penyebab tidak adanya keterbukaan.

Kondisi seperti inilah yang dapat diduga sebagai penyebab supervisi belum dilaksanakan dengan optimal. Kondisi tersebut dapat terjadi karena mungkin baik supervisor maupun pihak yang disupervisi belum benar-benar memahami makna dan

\footnotetext{
* Tenaga Pengajar di SMPN 99 Jakarta
} 
tujuan dari supervisi sehingga supervisor belum sepenuhnya dapat melaksanakan tugasnya secara utuh dan pihak yang disupervisi belum memahami manfaat dari supervisi. Pelaksanaan supervisi yang belum optimal akan memberi pengaruh terhadap kinerja guru di sekolah yang pada akhirnya akan berpengaruh terhadap hasil pembelajaran. Kunjungan atau supervisi yang dilaksanakan oleh sebagian besar kepala sekolah belum menyentuh sampai kepada makna yang diharapkan karena khususnya yang menyangkut supervisi untuk memantau pelaksanaan tugas guru. Maka dari itu penting kiranya untuk meneliti mengenai keterkaitan antara supervisi oleh kepala sekolah dengan kinerja guru di SMPN 99 Jakarta.

\section{Kinerja}

Kinerja dapat ditinjau dari berbagai sisi dan dimensi. Menurut Robbins (2007:231), kinerja sebagai hasil adalah hasil kerja seseorang sesuai dengan tanggung jawab dan hasil yang di harapkan. Kinerja itu sendiri merupakan wujud keberhasilan seseorang di dalam melaksanakan pekerjaan. Sedangkan menurt Moitorani (1995:131) mendefinisikan kinerja sebagai pernyataan sejauh mana seseorang telah memainkan perannya dalam melaksanakan strategi organisasi baik dalam mencapai sasaransasaran khusus yang berhubungan dengan peranan seseorang, dan atau dengan memperhatikan kompotensi-kompotensi yang dinyatakan relevan bagi organisasi, apakah dalam suatu peranan tertentu atau secara umum.

Bernardin dan Russel dalam Ruky (2006:15) memberikan definisi tentang performance sebagai berikut, "performance is defined as the record of out comes prouced on specified job function or activity during a specified time priod." Prestasi kerja adalah catatan tentang hasil-hasil dan bunga-bunga pekerjaan tertentu atau kegiatan tertentu selama kurun waktu tertentu. Mc. Cleand (2007:47) mendefinisikan kinerja sebagai cerminan dari keseluruhan cara seseorang dalam menetapkan tujuan prestasinya. Jadi seorang guru dalam melaksanakan tugas-tugas yang diberikan kepadanya harus direncanakan dengan baik sehingga tujuan yang telah ditetapkan dapat tercapai dengan baik.

Sedangkan Ivancevich dan Donnely yang diterjemahkan oleh Sulistyo (1992:32) mengungkapkan kinerja sebagai prestasi kerja, yaitu hasil yang diinginkan dari perilaku, prestasi kerja ini dapat ditentukan oleh interaksi seseorang terhadap kemampuan bekerja. Jadi seseorang guru dalam melaksanakan tugas-tugas yang diberikan kepadanya harus direncanakan dengan baik sehingga tujuan yang telah ditetapkan dapat tercapai dengan baik. Hasil interaksi antara seseorang terhadap kemampuan bekerja akan nampak menjadi hasil kerjanya lebih baik dan cepat maka itulah yang dinamakan kinerja. Lebih lanjut Casio dalam Ruky (2006:13) mendefinisikan "performance is the Systematic description of the job relevant strength and weaknesses of and individual or group". Kinerja sebuah gambaran/deskripsi sistematis tentang kekuatan dan kelemahan yang terkait dengan pekerjaan seseorang atau sesuatu kelompok. Guru yang profesional dan terampil dapat dikatakan memiliki kinerja yang baik, apalagi ditunjang dengan kemampuan bekerja sama dengan orang lain. Pada prinsipnya kinerja manusia berorientasi pada nilai-nilai

etos yang memotivasinya. Kinerja guru dapat dipengaruhi oleh berbagai faktor internal dan eksternal. Secara internal kinerja seseorang dipengaruhi oleh kemampuan, disiplin, sikap dan etos kerja. Sedangkan secara eksternal kinerja dipengaruhi oleh budaya organisasi, lingkungan kerja, baik fisik maupun non fisik, penilaian kerja, insentif, kepemimpinan kepala sekolah, perilaku manajerial, dan sebagainya. 
Berdasarkan uraian di atas, dapat disintesiskan kinerja merupakan prestasi kerja atau unjuk kerja guru, hasil kerja terhadap aktivitas selama periode tertentu dalam melaksanakan tugas sesuai dengan standar kerja yang telah ditetapkan. Oleh sebab itu maka yang menjadi indikator kinerja guru adalah prestasi kerja, tanggung jawab, kedisiplinan, kejujuran, kerja sama, dan insiatif.

\section{Persepsi}

Menurut Leavitt (1997:27), persepsi (perception) dalam arti sempit ialah; penglihatan, bagaimana cara seseorang melihat sesuatu, sedangkan dalam arti luas ialah pandangan atau pengertian, yaitu bagaimana seseorang memandang atau mengartikan sesuatu. Persepsi menurut Branca, Woodwort dan Marquia seperti dikutip Walgito (2002:69) mengatakan alat indera merupakan alat penghubung antara individu dengan dunia luarnya. Pendapat yang sama juga dikemukakan oleh Sekuler dan Blake (1994:1) dalam bukunya yang berjudul perception mengatakan bahwa persepsi merupakan proses yang berawal dari pengenalan tentang objek yang ada di sekitar lingkungan perceiver sampai pada proses penterjemahan atau pengambilan. Pengertian tentang objek tersebut pada suatu bentuk kegiatan aksi di dalam jaringan otak perceiver tersebut kemudian terlihat dalam reaksi tubuh perceiver tersebut tentang objek itu. Selanjutnya dijelaskan komponen dari suatu persepsi adalah: 1) lingkungan sekitar (sumber dari objek), 2) sensory system dari perceiver yaitu jaringan untuk menerjemahkan objek di lingkungan yang kemudian diaplikasikan dalam bentuk reaksi tubuh dari persepsipersepsi tersebut. Jika dicermati beberapa pendapat di atas, maka ada beberapa faktor yang berperan yaitu: 1) objek persepsi, 2) alat indera, syaraf dan pusat susunan syaraf, yang merupakan pusat susunan syaraf yakni syaraf fisiologis, 3) perhatian yang merupakan syarat psikologis.

Desiderato dikutip dari buku Irwanto (1996:71) menyatakan bahwa persepsi adalah peristiwa atau hubungan yang diperoleh dengan menyimpulkan informasi dan menafsirkan. Hal ini didukung oleh apa yang disampaikan oleh Sadli yang mengatakan persepsi seseorang merupakan suatu proses yang aktif. Adapun subjek yang melakukan persepsi yang dimaksud dalam tulisan ini adalah guru, maka terlebih dahulu dijelaskan yang dimaksud dengan guru adalah orang yang bertugas melaksanakan aktivitas pembelajaran di sekolah, selanjutnya kata guru menurut kepribadiannya adalah orang yang memiliki gagasan, usaha, rasa dan utama. Dari kalimat tersebut tampak bahwa guru adalah motor penggerak pelaksanaan pendidikan yang harus dilandasi dengan norma kemanusiaan yang luhur. Dijelaskan pula guru adalah orang yang bertugas mengajarkan ilmu pengetahuan, keterampilan dan sikap kepada orang lain. Didukung oleh pakar lain mengemukakan guru merupakan jabatan profesional yang memiliki tugas mendidik dan mengajar.

Berdasarkan beberapa teori di atas, dapat disintesiskan persepsi guru adalah perhatian, tangggapan dan pemberian makna terhadap suatu objek yang diterima melalui

indranya dalam konteks tertentu. Dalam hal ini guru dalam kaitannya dengan tugas sehari - hari berada di sekolah yang dipimpin oleh kapala sekolah sebagai supervisor.

\section{Supervisi}

Tugas kepala sekolah sebagai pemimpin adalah membantu para guru mengembangkan kesanggupan-kesanggupan mereka secara maksimal dan menciptakan suasana hidup sekolah yang sehat. Untuk itulah salah satu upaya untuk 
meningkatkan kinerja guru adalah melalui kegiatan pembinaan atau supervisi. Melalui supervisi akan diketahui kelemahan dan kekurangan dari guru dalam melaksanakan tugasnya di sekolah, sehingga dapat dijadikan acuan untuk memperbaiki dan meningkatkan produktivitas kerjanya. Menurt Wiles (1967:5), supervisi adalah kegiatan pelayanan yang diberikan kepada guru untuk membantu guru dalam melaksanakan tugasnya.

Neagley dan Evans (1980:20) mengemukakan bahwa supervisi merupakan pelayanan kepada guru-guru yang bertujuan untuk menghasilkan perbaikan instruksional, pembelajaran dan kurikulum. Definisi di atas memperlihatkan adanya ketegasan arah serta tujuan supervisi sebagaimana diungkapkan Knezevich (1984:132) bahwa "supervision as used in educational circles, is interpreted narrowly and related to teaching and learning activities and hence implies in instructional supervision". Supervisi yang digunakan dalam siklus penyelenggaraan pendidikan menunjukan arah kegiatan supervisi sebagai upaya pencapaian sasaran lembaga dan kinerja guru. Sedangkan Sergiovanni dan Starratt (2002:6) menekankan bahwa supervisi bertujuan membantu meningkatkan kesempatan dan kemampuan sekolah untuk memberikan kontribusi yang lebih efektif bagi keberhasilan akademik siswa.

Sementara itu Boardman yang dikutip oleh Subari (1994:4) menyatakan supervisi sebagai suatu usaha menstimulir, mengkoordinir, dan membimbing secara berlanjut pertumbuhan guru-guru baik secara pribadi maupun kelompok agar lebih memahami dan lebih efektif dalam mewujudkan seluruh fungsi pengajaran. Sementara itu Arikunto (2004:5) berpendapat bahwa supervisi adalah kegiatan mengamati, mengidentifikasi mana hal-hal yang sudah benar, yang belum benar, dan mana pula yang tidak benar, dengan maksud agar tepat dengan tujuan memberikan pembinaan. Sedangkan Subari (1994:4) juga berpendapat supervisi pendidikan adalah bantuan yang diberikan supervisor kepada guru agar ia mengalami pertumbuhan secara maksimal dan integral baik profesi maupun pribadinya. Berdasarkan penjelasan di atas jelaslah bahwa supervisi bukan kegiatan untuk mengawasi dan mencari-cari kesalahan guru tetapi memberikan bantuan kepada guru agar melaksanakan tugasnya dengan baik. Dengan demikian menurut Sahertian (2000:19) tujuan dari supervisi adalah memberikan layanan dan bantuan untuk mengembangkan situasi belajar mengajar yang dilakukan oleh guru di kelas. Oleh karena itu kegiatan pokok dari supervisi adalah melakukan pembinaan kepada sekolah dan guru pada umumnya. Supervisi berperan untuk mengoptimalkan tanggung jawab semua pihak dalam melaksanakan tugas dari seluruh program yang telah ditetapkan. Sebab itulah supervisi perlu dilakukan, karena melalui kegiatan supervisi guru akan mendapat masukan atas tugas-tugas yang telah dikerjakannya.

Lebih lanjut Glickman dalam Bafadal (1979:2) mendefinisikan supervisi pengajaran adalah serangkaian kegiatan membantu guru mengembangkan kemampunnya mengelola

proses belajar mengajar demi pencapaian tujuan pengajaran. Sergiovani yang dikutip oleh Bafadal (1995:25) menegaskan bahwa supervisi pengajaran memiliki tiga tujuan antara lain, sebagai pengawasan kualitas (supervisor bisa memonitor kegiatan proses belajar mengajar di sekolah), sebagai pengembangan pofesional (supervisor bisa membantu guru mengembangkan kemampuan dalam memahami pengajaran), sebagai motivasi guru (supervisor bisa mendorong guru menerapkan kemampuannya dalam melaksanakan tugas-tugas mengajarnya), mendorong kepada guru mengembangkan kemampuannya sendiri. Supervisi dapat dilakukan oleh pengawas sekolah atau kepala 
sekolah. Hal ini ditegaskan berdasarkan peraturan pemerintah No. 29 tahun 1990 tentang pendidikan menengah, bahwa pada jenjang pendidikan menengah selain pengawas, kepala sekolah juga mendapat tugas sebagai supervisor yang diharapkan dapat setiap kali berkunjung adalah ke kelas dan mengamati kegiatan guru yang sedang mengajar.

Sergiovani seperti yang dikutip oleh Bafadal (1979:25) merumuskan tentang tujuan supervisi pengajaran yaitu pengawasan kualitas pengawasan profesional, memotivasi guru. Tugas kepala sekolah sebagai supervisor adalah membantu guru dalam (1) pembinaan dan peningkatan profesi mengajar; (2) pembinaan dan peningkatan sikap personal dan sikap profesional.

Berdasarkan uraian di atas, dapat disintesiskan pelaksanaan supervisi oleh kepala sekolah adalah serangkaian pelayanan oleh kepala sekolah dalam pembinaan, pengawasan, pembimbingan dan pelatihan untuk membantu guru dalam meningkatkan kinerja guru.

\section{Keterkaitan Antara Supervisi oleh Kepala sekolah dan Kinerja Guru}

Menurut A. Sahertian (2008), kepala sekolah adalah pemimpin di sekolah yang merupakan salah satu faktor penting di sekolah dalam menggerakan semua potensi dan sumber daya yang ada. Supervisi juga sebagai kegiatan pelayanan yang diberikan kepala sekolah kepada guru untuk membantu guru dalam melaksanakan tugasnya. Dengan demikian dapat dikatakan bahwa guru akan menunjukan hasil kerja yang baik jika pimpinan dalam hal ini adalah kepala sekolah dapat melakukan supervisi dengan baik. Kinerja merupakan prestasi kerja atau unjuk kerja guru, hasil kerja terhadap aktivitas selama periode tertentu dalam melaksanakan tugas sesuai dengan standar kerja yang telah ditetapkan. Guru yang mempunyai kemampuan yang baik dan memiliki sifat yang tekun dan ulet dalam bekerja tentunya akan menunjukan hasil kerja yang baik. Banyak hal yang mempengaruhi kinerja pegawai (guru). Menurut Simamora seperti yang dikutip oleh Mangkunegara (2006:14) bahwa kinerja dipengaruhi oleh tiga faktor, yaitu: (1) faktor individu yang terdiri dari: (a) kemampuan dan keahlian, (b) latar belakang dan (3) demografi, (2) faktor demografi yang terdiri dari: (a) persepsi, (b) attitude (c) personality, (d) pembelajaran, (e) motivasi, (3) faktor organisasi yang terdiri dari: (a) sumber daya, (b) kepemimpinan, (c) penghargaan, (d) strukur, dan (e) job design.

Dari beberapa hal yang mempengaruhi kinerja seperti diuraikan di atas maka salah satu faktor yang mempengaruhi kinerja pegawai (guru) adalah pimpinan (kepala sekolah). Seorang guru akan menunjukan hasil kerjanya dengan baik jika kepala sekolah yang berada di sekolah melakukan supervisi dengan baik.

Berdasarkan uraian di atas, dapat disintesiskan salah satu usaha kepala sekolah untuk meningkatkan prestasi kerja guru dengan cara melaksanakan supervisi. Hal ini berarti bahwa pelaksanaan supervisi oleh kepala sekolah terhadap guru untuk dapat meningkatkan prestasi hanya perlu dilaksanakan dengan baik.

\section{METODE}

Metode yang digunakan dalam penelitian ini adalah metode deskriptif-kuantitatif. Ini bertujuan untuk mendeskripsikan suatu fakta ataupun fenomena melalui data terkuantifikasi tanpa dilakukan pengujian hipotesis. Penelitian ini dilakukan di SMPN 99 Jakarta. Kegiatan penelitian pada bulan Juni 2009 sampai dengan Agustus 2009. Pada penelitian ini sumber data primer diperoleh dari penyebaran instrumen kepada 57 
orang guru tetapi yang terjangkau sebanyak 30 orang guru SMPN 99 Jakarta, yang ditetapkan sebagai responden, sedangkan data sekunder adalah dokumen dan fenomena artifact yang berhubungan dan relevan dengan kegiatan penelitian ini. Data yang diperlukan pada penelitian dikumpulkan dengan menggunakan beberapa teknik antara lain : penyebaran angket, observasi, studi dokumentasi, dan wawancara.

\section{HASIL DAN PEMBAHASAN}

Berdasarkan temuan penelitian di lapangan diperoleh gambaran bahwa supervisi yang digunakan kepala sekolah dalam melakukan pembinaan adalah kepala sekolah memberikan arahan dan bimbingan dalam hubungan mitra kerja dan bukan sebagai atasan dan bawahan. Teknik supervisi yang dilakukan kepala sekolah dalam memberikan pembinaan yaitu dengan mengadakan diskusi atau dialog secara pribadi antara kepala sekolah dengan guru setelah memperoleh informasi tentang guru yang bersangkutan. Kepala sekolah juga mengadakan rapat rutin yang bertujuan mengevaluasi pelaksanaan tugas guru. Selain itu kepala sekolah mengaktifkan kegiatan MGMP di sekolah dan mengikutsertakan guru untuk seminar. Pembinaan diberikan kepala sekolah dengan memberikan bantuan layanan kepada guru berupa arahan dan bimbingan baik atas inisiatif kepala sekolah maupun guru berupa arahan dan bimbingan baik atas inisiatif kepala sekolah maupun guru itu sendiri. Dalam melakukan pembinaan kepala sekolah dibantu oleh wakil kepala sekolah dan koordinator MGMP yang merupakan tim supervisi. Serta bekerja sama dengan Dinas Pendidikan setempat. Pembinaan dilakukan kepada semua guru secara kontinu baik secara individual maupun kelompok dengan menetapkan jadwal pembinaan.

Dalam teori supervisi, merupakan aspek yang pokok. Sebagaimana yang dikemukakan oleh Crosby yang dikutip oleh Burhanudin (1988:102) menyatakan bahwa supervisi adalah pembinaan yang diberikan kepada seluruh staf sekolah agar mereka dapat meningkatkan kemampuan untuk mengembangkan situasi belajar mengajar yang lebih baik. Imron (2002:12) berpendapat bahwa supervisi bertujuan bahwa untuk meningkatkan kemampuan profesional guru dalam melaksanakan tugasnya melalui pemberian bantuan berupa layanan profesional kepada guru. Pernyataan di atas menunjukan bahwa supervisi dilakukan dengan tujuan untuk memberikan pembinaan kepada guru dalam rangka meningkatkan kinerja guru dalam melaksanakan tugasnya. Harjana (1991:12) mengungkapkan bahwa pembinaan adalah suatu proses belajar dengan

mempelajari hal-hal baru yang belum dimiliki dengan tujuan untuk membetulkan dan mengembangkan pengetahuan dan kecakapan yang sudah dimiliki serta untuk mendapatkan pengetahuan dan kecakapan yang baru untuk mencapai tujuan hidup dan kerja yang sedang dijalin secara efektif.

Dengan membandingkan temuan penelitian dengan teori supervisi sebagai pembinaan, maka dapat dijelaskan bahwa supervisi yang digunakan kepala SMPN 99 Jakarta dalam melakukan pembinaan terhadap guru dengan memberikan arahan dan bimbingan dalam hubungan mitra kerja dan bukan sebagai atasan dan bawahan serta adanya hubungan dua arah yang baik antara kepala sekolah dengan guru. Keberhasilan suatu pembinaan diharapkan dapat menghasilkan perkembangan pada pribadi guru, antara lain dapat berupa unjuk kerja yang lebih baik, di mana senantiasa diawali dengan adanya perencanaan yang matang atas dasar kebutuhan serta selalu berorientasi kepada apa yang akan terjadi pada masa yang akan datang. 
Supervisi oleh kepala sekolah dalam aspek cara memberikan motivasi dapat meningkatkan kualitas dan kuantitas kerja yang dibutuhkan. Motivasi yang diberikan sangat bervariasi antara guru satu dengan yang lainnya. Motivasi biasa dalam bentuk penghargaan, bonus, promosi jabatan dalam diri guru itu sendiri (intrinsik). Motivasi intrinsik ini akan lebih besar pengaruhnya terhadap diri seseorang karena sudah ada dorongan dari diri seseorang untuk melakukan pekerjaan.

Kinerja seorang guru akan bisa dipengaruhi oleh bagaimana supervisi oleh kepala sekolah dalam aspek cara memberikan pelatihan kepada guru. Guru yang merasa kepala sekolah tidak memberikan pelatihan baik melalui kursus komputer atau workshop akan berpengaruh negatif pada kemampuan sumber daya guru tersebut, yang pada akhirnya semangat kerja akan menurun. Dalam suatu organisasi pendidikan, pelatihan merupakan bagian yang tidak terpisahkan dari suatu sistem, yaitu sistem pengembangan sumber daya manusia. Pelatihan merupakan salah satu upaya yang dapat dilakukan dalam meningkatkan kinerja guru. Menurut Jhonson yang dikutip Imron (2002:9) pelatihan diperlukan bagi guru karena adanya realitas yang menunjukkan guru untuk belajar, karena jika tidak maka akan ketinggalan dengan laju perkembangan zaman.

Robinson (2002) menyatakan bahwa pendidikan dan pelatihan merupakan serangkaian kegiatan pendidikan yang mengutamakan perubahan pengetahuan, keterampilan dan peningkatan sikap seorang pegawai dalam melaksanakan tugasnya. Dari pelatihan diharapkan semua karyawan dapat meningkatkan dirinya baik pengetahuannya maupun keterampilanya. Harapan lainnya yaitu sikap pegawai menjadi lebih matang dalam arti matang untuk menghadapi perubahan yang terjadi. Briggs yang dikutip oleh Imron (2002:13) menyatakan bahwa fungsi Supervisi adalah untuk mengkoordinasi, menstimulasi usaha-usaha yang kreatif, memberi fasilitas dan penilaian

yang terus menerus, menganalisis situasi belajar mengajar, memberikan pengetahuan dan keterampilan guru serta staf, mengintegrasikan tujuan pendidikan dan membantu meningkatkan kemampuan guru. Sedangkan Boardman yang dikutip oleh Subari (1994:5) menyatakan Supervisi sebagai suatu usaha menstimulir, mengkoordinir, dan membimbing secara berlanjut pertumbuhan guru-guru baik secara pribadi maupun kelompok agar lebih memahami dan lebih efektif dalam mewujudkan seluruh fungsi pengajaran.

Berdasarkan uraian di atas, dapat disintesikan bahwa supervisi dilakukan untuk menambah pengetahuan dan keterampilan guru dalam rangka meningkatkan kemampuan guru. Maka jelaslah pelatihan yang diberikan kepada guru merupakan bagian dari supervisi. Berdasarkan temuan penelitian di lapangan kepala sekolah memberikan pelatihan disesuaikan dengan aspirasi dan kebutuhan yang diperlukan guru dalam melaksanakan tugasnya. Agar guru dapat lebih meningkatkan kemampuannya dalam menjalankan tugas. Dengan demikian diharapkan dapat meningkatkan kinerja guru.

\section{PENUTUP}

Kesimpulan. Secara deskriptif antara supervisi dengan kinerja guru memiliki keterkaitan yang berarti/positif. Semakin tinggi tingkat supervisi maka akan semakin baik pula kinerja guru. Demikian pula sebaliknya semakin rendah tingkat supervisi maka akan semakin rendah pula kinerja guru di SMPN 99 Jakarta. 
Saran. Pertama, SMPN 99 Jakarta agar dapat mempertahankan Supervisi yang sudah ada serta diupayakan peningkatan di masa yang akan datang. Kedua, SMPN 99 Jakarta dapat meningkatkan kinerja gurunya di masa yang akan datang sehingga visi dan misi sekolah dapat tercapai dengan baik. Ketiga, SMPN 99 Jakarta hendaknya senantiasa menerapkan supervisi yang dapat meningkatkan kinerja para guru yang pada akhirnya meningkatkan prestasi para gurunya.

\section{DAFTAR RUJUKAN}

Arikunto, Suharsimi. Dasar-Dasar Supervisi. Jakarta: Rineka Cipta, 2004.

Bafadal, Ibrahim. Supervisi Pengajaran Teori dan Aplikasinya Dalam Membina Profesional Guru. Jakarta: Rineka Cipta, 1979.

Boardman, et al. Democratic Supervision In Secondary School (Cambridge Massacuttes: Houghton Miffin Company, 1953. yang di kutip oleh Subari Supervisi Pendidikan dalam Rangka Perbaikan Situasi Mengajar. Jakarta: Bumi Aksara, 1994.

Burhanudin. Analisis Administrasi Pendidikan. Jakarta: Bumi Aksara, 1994.

Burhanudin, Yusak. Administrasi Pendidikan. Bandung: Pustaka Setia, 1988.

Idris, Zahara dan Lisda Jamal. Pengantar Pendidikan. Jakarta: Gramedia, 1992.

Imron, Ali. Pembinaan Guru Di Indonesia. Jakarta: Bumi Aksara, 2002.

Irwanto, dkk. Psikologi umum. Jakarta: PT. Gramedia, 1996.

JH, Dennely. Organisasi dan Manajemen terjemahan, H. Sulistyo. Jakarta: Erlangga, 1992.

Knezevich, Stephen, J. Administration Of Public Education. New York: Harpercollins Publishers, 1984.

Leavit, Harold J. Psikology Manajement terjemahan muslihah Zarkasi. Jakarta: PT Gelora Aksara Pratama, 1997.

Mangkunegara, A.A. Anwar Prabu. Evaluasi Kinerja SDM. Bandung: PT Refika Aditama, 2006.

Mangunharjana. Pembinaan,: Arti dan metodenya. Yogyakarta: Kanisius, 1991.

Motrani, Alain. Manajemen Sumber Daya Manusia Berdasarkan Kompetens. Jakarta: Pustaka Utama Grafika, 1995.

Neagley, Rose L. and N. Dean Evans. Handbook for effective Supervison of Instruction. Englewood Cliffs. New Jersey: Prentice Hall, 1980.

Robbin, Stephen P. Essential of Organizational Behaviour. New Jersey: Prentice - Hal International Inc, 2007.

Ruky, Ahmad S. Manajemen Kinerja. Jakarta: Gramedia Pustaka Utama, 2006.

Sahertian, Piet A. Konsep Dasar dan Teknik Supervisi Pendidikan. Jakarta: Rineka Cipta, 2000.

Sekuler, Robert, et al. Perception. Brandies University: Mc. Graw Hill, 1994. 
Sergiovanni, Thomas J. and Robert J. Strratt. Supervision A Redefinition. New York: Mc Graw-Hill, 2002.

Sergiovanni, Thomas J. The Principalship: A Reflective PracticePerspektive. Boston: Ally and Bacon, Inc, 1987. dikutip oleh Ibrahim Bafadal, Supervisi Pengajaran. Semarang: Bumi Aksara, 1995.

Subari. Supervisi Pendidikan Dalam Rangka Perbaikan Situasi Mengajar. Jakarta: Bumi Aksara, 1994.

Walgito, Bimo. Psikologi Umum. Yokyakarta: Andi, 2002.

Wiles, Kimbal. Supervision For BetterSchools. London: Prentice-Hall, Inc, 1967. 